\title{
Preparation of an experimental low-fluoride diet from single-cell organisms for rats and mice
}

\author{
By S. A. KHALAWAN, J. C. ELLIOTT AND R. W. FEARNHEAD \\ Department of Dental Anatomy, The London Hospital Medical College, \\ Turner Street, London EI $2 A D$
}

(Received 17 October 1979 - Accepted 20 June 1980)

\begin{abstract}
I. A method for producing a standard low-fluoride diet from a green alga and yeast is described. Chlorella pyrenoidosa was grown in a culture medium prepared with distilled water and analytical grade chemical salts. The spent culture medium from the alga culture was reclaimed and replenished with salts and sucrose for the production of yeast, Saccharomyces cerevisiae.

2. The single-cell organisms were separated by centrifugation from their culture media and the dried cells were blended with sucrose, maize oil, cellulose and a salt mix to produce diet pellets for rats and mice.

3. The diet was readily accepted as food by rats and mice and it was found to contain $100-300 \mu \mathrm{g}$ fluoride/ $\mathrm{kg}$ dry weight. Two generations of rats and four generations of mice were bred on this diet.

4. The use of hydroxyapatite to reduce the fluoride content of the chemicals used in the production of the alga and yeast biomass was investigated. Diet pellets prepared with this biomass contained 45-60 $\mu \mathrm{g}$ fluoride/ kg dry weight.
\end{abstract}

Fluoride confers a marked amount of protection against the incidence of dental caries (Adler, 1970). The nature of the role played by fluoride in mineralization of hard tissues is difficult to test because of the problems in obtaining a low-fluoride diet prepared with a sufficiently high extent of purity and control. Fluorine has presented this enormous difficulty because of its widespread distribution and high chemical reactivity.

The present study was an attempt to prepare a diet from single-cell organisms (the yeast Saccharomyces cerevisiae, and the alga Chlorella pyrenoidosa) under controlled conditions and to evaluate its use as a low-fluoride diet for rats and mice.

Additional experiments were performed to investigate the removal of fluoride from some of the commercially available analytical grade chemicals used. This was based on the observation that fluoride ions react readily with hydroxyapatite, $\mathrm{Ca}_{5}\left(\mathrm{PO}_{4}\right)_{3} \mathrm{OH}$ (Volker et al. 1940) to produce the more stable fluorapatite, $\mathrm{Ca}_{5}\left(\mathrm{PO}_{4}\right)_{3} \mathrm{~F}(\mathrm{McCann} \& \mathrm{Fath}, \mathrm{I958})$.

\section{Previous work on production and study of Chlorella and yeast foodstuffs}

Production of Chlorella in mass culture (Ketchum et al. 1949) and its use as a food (Casey \& Lubitz, 1963) has been reported. It has a relatively high vitamin content: provitamin A, B-group vitamins, vitamin $C$ and $\beta$-tocopherol (Endo \& Shirota, 1972; Endo et al. 1974), and a relatively high concentration of essential amino acids except methione and cystine (Fowden, 1952; Lubitz, 1963). The relative proportions of protein and lipid vary enormously according to the culture conditions (Spoehr \& Milner, I949; Spoehr, 1951), but the protein content is higher than vegetables such as soya bean and cereals commonly used as livestock and poultry feed (Spoehr, 195I ; Combs, 1952). The lipids consist of approximately $50 \%$ fatty acids of which some $80 \%$ is unsaturated (Paschke \& Wheeler, 1954; Schlenk et al. 1960).

Yeast has been used as a food additive for over 30 years because of its high quality of concentrated protein and abundance of B-complex vitamins. Yeast protein is highly 


\section{S. A. Khalawan, J. C. Elliott and R. W. Fearnhead}

digestible in man (Murlin et al. 1944), and when supplemented with methionine, the protein utilization efficiency in the rat is almost as high as that of casein (Klose \& Fevold, I947; Harris et al. 1951).

\section{EXPERIMENTAL}

Chlorella pyrenoidosa

Culture vessels of clear acrylic cylinders $150 \mathrm{~mm}$ diameter and $\mathrm{I} \mathrm{m}$ tall were fitted with removable lids with a small hole for a plastic tube for the supply of compressed air ( $1.51 / \mathrm{min}$ ) to the bottom of the cylinder. Eighteen cylinders (total volume $250 \mathrm{l}$ ) were mounted against a white wall fitted with three horizontal rows of tubular fluorescent lamps (total power $630 \mathrm{~W}$, but this was varied to keep the temperature of the medium between $\left.25-28^{\circ}\right)$.

The culture medium (Table I) was based on Myers' nutrient solution for Chlorella (Myers, 1947) and was made up with analytical grade reagents in distilled water. The $\mathrm{pH}$ of the freshly-prepared culture medium was between 6.5 and 6.6 and showed little change from inoculation to the time of harvest (6-8 d).

Table r. Composition $(\mid l)$ of culture medium for Chlorella pyrenoidosa

\begin{tabular}{|c|c|}
\hline $\begin{array}{l}\text { Major salts (mg) } \\
\mathrm{NH}_{4} \mathrm{NO}_{3} \\
\mathrm{NH}_{4} \mathrm{H}_{2} \mathrm{PO} \\
\mathrm{K}_{2} \mathrm{HPO}_{4} \\
\mathrm{MgSO}_{4} \cdot 7 \mathrm{H}_{2} \mathrm{O} \\
\mathrm{FeSO}_{4} \cdot 7 \mathrm{H}_{2} \mathrm{O} \\
\mathrm{Na}_{3} \mathrm{EDTA} \\
\mathrm{H}_{3} \mathrm{BO}_{3} \\
\mathrm{MnCl}_{2} \cdot 4 \mathrm{H}_{2} \mathrm{O}\end{array}$ & $\begin{array}{r}340 \\
330 \\
400 \\
215 \\
20 \\
25 \\
3 \\
2\end{array}$ \\
\hline $\begin{array}{l}\text { Minor salts }(\mu \mathrm{g}) \\
\mathrm{ZnSO}{ }_{4} \cdot 7 \mathrm{H}_{2} \mathrm{O} \\
\mathrm{CuSO}_{4} \cdot 5 \mathrm{H}_{2} \mathrm{O} \\
\mathrm{NaMoO}_{4} \cdot 2 \mathrm{H}_{2} \mathrm{O} \\
\mathrm{Co}\left(\mathrm{NO}_{3}\right)_{2} \cdot 6 \mathrm{H}_{2} \mathrm{O}\end{array}$ & $\begin{array}{l}0.250 \\
0.025 \\
0.015 \\
0.015\end{array}$ \\
\hline
\end{tabular}

The medium was inoculated with a vigorously growing culture of Chlorella from the previous batch. A Sharples Continuous Laboratory Centrifuge (Type Mv 4I 24Y 8RY; Penwalt Ltd, Doman Road, Surrey) was employed for harvesting the algal cells, which were stored at $-30^{\circ}$.

\section{Saccharomyces cerevisiae}

The spent Chlorella culture medium was supplemented with salts (analytical grade) and vitamins (Table 2) and used for culturing the yeast in four 501 polyethylene containers. Compressed air $(3 \mathrm{l} / \mathrm{min})$ was bubbled through the culture medium which was kept near pH 4.5 with ammonium hydroxide and at $28-30^{\circ}$ throughout the growth period ( $4 \mathrm{~d}$ ). The yeast cells were harvested in the same manner as the Chlorella cells and dried at $35-40^{\circ}$ and stored at $-30^{\circ}$.

Table 2. Supplement $(/ l)$ added to spent Chlorella pyrenoidosa medium for culturing yeast (Saccharomyces cerevisiae)

$\begin{array}{lr}\text { Sucrose (g) } & \text { I5 } \\ \text { Ammonium chloride }(\mathrm{mg}) & 450 \\ \text { Potassium dihydrogen phosphate }(\mathrm{mg}) & 300 \\ \text { Meso-inositol }(\mu \mathrm{g}) & 500 \\ \text { Calcium pantothenate }(\mu \mathrm{g}) & 200 \\ \text { Thiamine }(\mu \mathrm{g}) & 150 \\ \text { Biotin }(\mu \mathrm{g}) & 3\end{array}$




\section{Production of food pellets (Chlorycel)}

The frozen yeast and Chlorella were heated in a microwave oven in order to thaw and kill the cells as well as destroy any spoilage micro-organisms present. The ingredients (Table 3 ) were then thoroughly mixed in a food-mixer and made into pellets $(25 \times 15 \times 10 \mathrm{~mm})$ using plastic utensils to minimize fluoride contamination. Although pellets stored at room temperature for I week showed no apparent sign of deterioration, refrigeration was employed as a precaution against contamination by air-borne organisms and oxidative decomposition.

Maize oil (Table 3) was added as a lipid supplement, for improving the texture of the diet, and as a vehicle for the fat-soluble vitamins. Cellulose in the form of a fibrous powder was used to provide bulk, to add to the fibre content of the diet, and to improve the texture.

Table 3. Ingredients $(\mathrm{g} / \mathrm{kg}$ ) of yeast (Saccharomyces cerevisiae) and alga (Chlorella pyrenoidosa) food pellets (Chlorycel)

$\begin{array}{lr}\text { Yeast } & 500 \\ \text { Chlorella } & 70 \\ \text { Sucrose } & 250 \\ \text { CaHPO } .2 \mathrm{H}_{2} \mathrm{O} & 10 \\ \text { Calcium carbonate } & 10 \\ \text { Methionine } & 5 \\ \text { Salt mix } & 4 \\ \text { Cellulose } \dagger & 120 \\ \text { Vitamin-enriched maize oil } & 35\end{array}$

- Contained $(\mathrm{g} / \mathrm{kg})$ analytical grade salts, $\mathrm{MgSO}_{4} \cdot 7 \mathrm{H}_{2} \mathrm{O} 250, \mathrm{MnCl}_{2} \cdot 4 \mathrm{H}_{2} \mathrm{O} 200$, FeSO $.7 \mathrm{H}_{2} \mathrm{O} 50$, $\mathrm{ZnSO}_{4} .7 \mathrm{H}_{2} \mathrm{O} 60, \mathrm{CuSO}_{4} .5 \mathrm{H}_{2} \mathrm{O} 30, \mathrm{KI} 15, \mathrm{NaCl}_{375}, \mathrm{Co}\left(\mathrm{NO}_{3}\right)_{2} .6 \mathrm{H}_{2} \mathrm{O}$ 10, $\mathrm{NaMoO}_{4} .2 \mathrm{H}_{2} \mathrm{O}$ ro.

$\dagger$ Supplied by Reeve Angel and Co. Ltd, London SEr.

¥ Pharmaceutical grade maize oil (Evans Medical Ltd, Liverpool) enriched with $(/ l)$ I.5 g DL- $\alpha$ tocopherol, $440 \mathrm{mg}$ retinol and $3 \mathrm{mg}$ ergocalciferol.

\section{Reduction of the fluoride level in chemical salts}

Three separate samples of the diet were prepared with biomass grown in culture media prepared with analytical grade salts in which the fluoride level was reduced by the following procedure:

Hydroxyapatite was prepared with equal volumes of $0.3 \mathrm{M}-\left(\mathrm{NH}_{4}\right)_{2} \mathrm{HPO}_{4}$ and $0.5 \mathrm{M}-\mathrm{Ca}\left(\mathrm{NO}_{3}\right)_{2}$ solutions at $\mathrm{pH}$ I0.5 and characterized by X-ray powder diffraction. The stock salt solutions used for preparing the culture media were shaken with the dry, finely powdered hydroxyapatite (approximately $10 \mathrm{~g} / \mathrm{l}$ ) for 5-10 $\mathrm{min}$ and filtered. The Ca salt supplements used for the preparation of these samples of the diet ('low-fluoride Chlorycel') were prepared with hydroxyapatite-treated reagent solutions in a similar manner.

\section{Animal studies}

Two pairs of weanling litter-mate Sprague-Dawley rats were used to commence a multigeneration study. One pair was fed the experimental diet and the other (the controls) was fed a commercial diet, 4I B (E. Dixon \& Sons Ltd, Crane Mead Mills, Ware, Hertfordshire). The quantity of experimental diet was insufficient for the growing colony of rats so they were replaced with mice, in order to continue the study. Two pairs of weanling litter-mate albino mice (The Wright Fleming Institute, St Mary's Hospital Medical School, Praed Street, London) were used as parents in this second multigeneration experiment. One pair was used as experimental and the other as controls. The control mice were fed with a commercial diet, FFG(M) (E. Dixon \& Sons Ltd, Ware, Herts). 


\section{S. A. Khalawan, J. C. Elliott and R. W. Fearnhead}

Metabolic studies, with four-week-old litter-mate female Harvard rats, were conducted over periods of 7 weeks in two separate experiments. In the first, there were three experimental and two controls; in the second, there were four experimental and three control rats. The experimental rats were exclusively fed on Chlorycel and the controls the laboratory diet, $4 \mathrm{IB}$.

The rats and mice in the multigeneration experiments were kept under identical conditions to other rats and mice in the laboratory except that the experimental animals were exclusively fed on Chlorycel. The animals were housed in conventional plastic cages with stainless steel wire lids and provided with wood shavings for litter and nesting material. The rats in the metabolic study were housed individually in glass metabolism cages (Jencons Ltd, Mark Road, Hemel Hempstead, Herts). Food and water were supplied ad lib. to all the animals.

The rats and mice were examined daily for signs of ill-health and unusual behaviour. Body-weights of the animals were recorded weekly in the multigeneration experiments and daily in the metabolic experiments. Breeding pairs of litter-mates were caged together at the age of 12 weeks and the male was removed from the cage before the litter was born. The same pair was brought together again for mating, after the previous litter was weaned.

\section{Analytical methods}

Amino acids. The method of Spackman et al. (1958) was used.

Elements. $\mathrm{Ca}, \mathrm{Mg}, \mathrm{Fe}, \mathrm{Mn}, \mathrm{Zn}$ and $\mathrm{Cu}$ were analysed by optical emission spectroscopy. $\mathrm{Na}$ and $\mathrm{K}$ were determined by atomic absorption and phosphorus by the phosphomolybdate colorimetric method.

Fluoride. Fluoride was recovered by microdiffusion (Singer \& Armstrong, 1965) and measured with a fluoride electrode.

Protein-nitrogen. The Kjeldahl method was used.

Apparent digestibility. The apparent digestibility of the diets fed to the rats in the second metabolic experiment was based on the nitrogen content of the diets and faeces of the rats. It was calculated from the equation:

$$
\text { Percentage apparent digestibility }=\frac{\text { Diet } \mathbf{N}-\text { Faecal } \mathbf{N}}{\text { Diet } \mathbf{N}} \times 100 .
$$

\section{RESULTS}

\section{Biomass and diet}

The yield of algal cells was $6-8 \mathrm{~g}$ wet weight/1 culture medium. A Chlorella culture of 1201 produced approximately $100 \mathrm{~g}$ dry weight biomass and 2001 yeast culture produced approximately $700 \mathrm{~g}$. The protein content (based on the Kjeldahl method) of the dried yeast was $450-500 \mathrm{~g} / \mathrm{kg}$ and of Chlorella $400-500 \mathrm{~g} / \mathrm{kg}$. Their amino acid compositions are given in Table 4. These results are comparable to published values for Chlorella (Fowden, I954) and yeast (Lindan \& Work, I95I). Methanol-diethyl ether extraction indicated approximately $20 \mathrm{~g}$ lipid $/ \mathrm{kg}$ dried yeast and approximately $80 \mathrm{~g}$ lipid $/ \mathrm{kg}$ dried Chlorella. The total ash contents of Chlorella and yeast were approximately $60 \mathrm{~g} / \mathrm{kg}$. The chemical composition of Chlorycel is given in Table 5. It should be noted that the protein content given in Table 5 is based on the amino acid concentration in the biomass and not on the total nitrogen content. The range of fluoride concentration given in Table 5 was obtained from eleven pooled samples of Chlorycel, each containing material from not less than ten batches of diet. 
Table 4. Amino acid composition of the Chlorella pyrenoidosa and yeast (Saccharomyces cerevisiae) dry matter

\begin{tabular}{lcc} 
Amino acid & Nitrogen content (\% N recovered) \\
\cline { 2 - 3 } & Yeast & Chlorella \\
Aspartic acid & 7.20 & 6.67 \\
Threonine & 4.43 & 4.12 \\
Serine & 5.43 & 4.41 \\
Glutamic acid & 8.83 & 7.28 \\
Proline & 3.73 & 5.83 \\
Glycine & 5.60 & 8.24 \\
Alanine & 9.85 & 10.47 \\
Cysteine & 0.36 & 0.47 \\
Valine & 4.61 & 5.42 \\
Methionine & 0.65 & $1 \cdot 33$ \\
Isoleucine & 4.06 & 3.05 \\
Leucine & 5.36 & 6.94 \\
Tyrosine & 2.22 & 2.09 \\
Phenylalanine & 2.55 & 3.34 \\
Histidine & 10.22 & 4.38 \\
Lysine & 10.19 & 8.09 \\
Arginine & 11.42 & 15.00
\end{tabular}

Table 5. Chemical composition $(\mathrm{g} / \mathrm{kg})$ of yeast (Saccharomyces cerevisiae) and alga (Chlorella pyrenoidosa) food pellets (Chlorycel)

$\begin{array}{lc}\text { Protein* } & 190 \\ \text { Carbohydrates } & 250 \\ \text { Lipid } & 50 \\ \text { Fibre } & 120 \\ \text { Ash } & 50 \\ \text { Calcium } & 6.3 \\ \text { Phosphorus } & 7 \cdot 0 \\ \text { Sodium } & 0.72 \\ \text { Magnesium } & 0.76 \\ \text { Iron } & 0.24 \\ \text { Manganese } & 0.24 \\ \text { Zinc } & 0.085 \\ \text { Copper } & 0.029 \\ \text { Fluoride (mg/kg) } & 0.1-0.3 \S\end{array}$

- Value calculated from the amino acid content of the alga (approximately $32 \%$ protein) and yeast (approximately $33 \%$ protein) and including the methionine supplement $(5 \mathrm{~g} / \mathrm{kg}$ ).

$\dagger$ The carbohydrate content of the alga and yeast was not determined and is not included. The $250 \mathrm{~g} / \mathrm{kg}$ carbohydrate is represented by sucrose.

¥ This value does not include the fibre content of the cellular material in the diet.

$\S$ Mean $( \pm$ SD $) 0.18( \pm 0.07)$.

\section{Animal studies}

Chlorycel was readily accepted as food by the rats and mice. The rats were bred through two generations and the mice through four successive generations fed exclusively with this diet. The breeding pattern for the mice is given in Fig. I. The results of the breeding experiments are given in Table 6 for the rats and Table 7 for the mice. First litter mice were mainly used for breeding subsequent generations (Fig. I) in order to make maximum use of the small quantity of Chlorycel. In the third generation $\left(F_{3}\right)$ there were only three litters of control mice compared with four litters of experimental mice (Table 7 ) because the first litter $F_{2}$ control dam died shortly after her second litter $\left(F_{3}\right)$ was weaned. However, the number of pups born and weaned in the experimental group was similar to those in the 


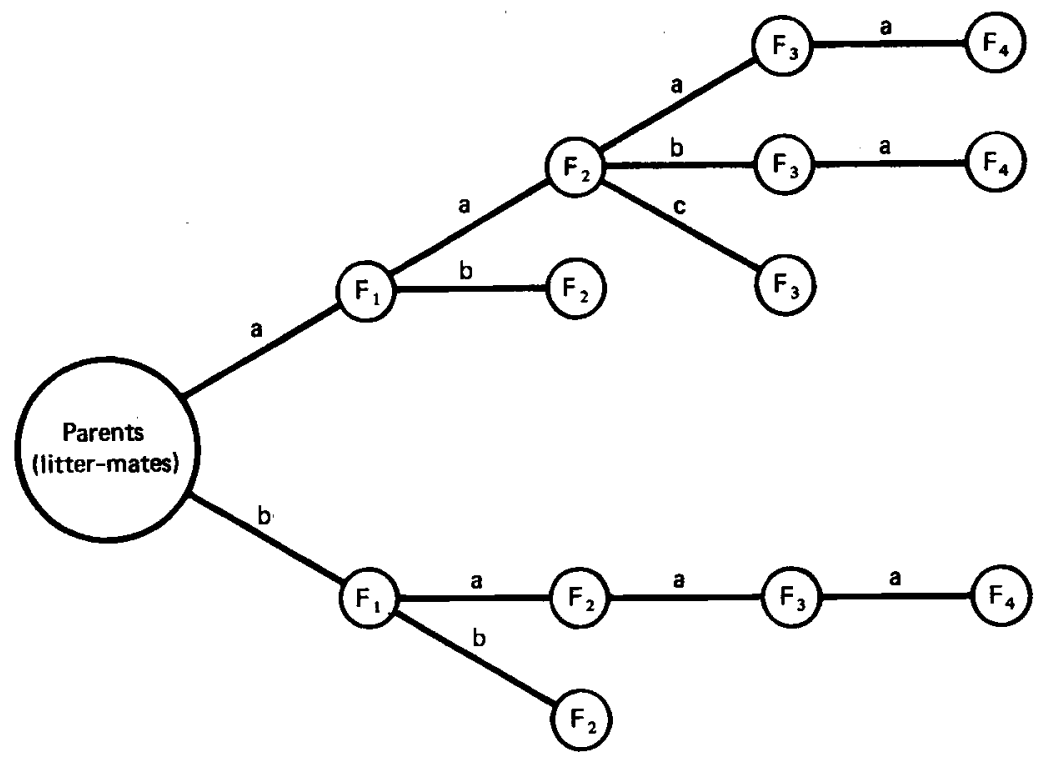

Fig. I. Breeding chart for a group of mice fed exclusively with yeast (Saccharomyces cerevisiae) and alga (Chlorella pyrenoidosa) food pellets (Chlorycel) over four successive generations. The breeding pairs were litter-mates. a, First litter; b, second litter; c, third litter.

Table 6. Breeding experiment results for two successive generations of rats*

$\begin{array}{cccccc}\begin{array}{c}\text { Generation } \\ \mathbf{F}_{1}\end{array} & \begin{array}{c}\text { No. of } \\ \text { litters }\end{array} & \overbrace{\text { No. born }} & \text { No. weaned } & & \overbrace{\text { No. born }}^{\text {Exper weaned }} \\ \mathbf{F}_{2} & 1 & 16 & 14 & 14 & 13 \\ 12 & 12 & 11 & 12 & 12\end{array}$

- The experimental rats were fed exclusively with yeast (Saccharomyces cerevisiae) and alga (Chlorella pyrenoidosa) food pellets (Chlorycel) and the controls were fed a commercial diet (4IB).

Table 7. Breeding experiment results for four successive generations of mice*

$\begin{array}{ccccccc}\text { Generation } & \begin{array}{c}\text { No. of } \\ \text { litters }\end{array} & \overbrace{\text { No. born }} & \text { No. weaned } & \overbrace{\text { No. born }}^{\text {No. weaned }} \\ F_{1} & 2 & 16 & 16 & & 15 & 14 \\ F_{2} & 4 & 24 & 23 & 27 & 24 \\ F_{3} & 4 \dagger & 32 & 26 & 22 & 21 \\ F_{4} & 3 & 14 & 12 & 18 & 17\end{array}$

* The experimental mice were fed exclusively with yeast (Saccharomyces cerevisiae) and alga (Chlorella pyrenoidosa) food pellets (Chlorycel) and the controls were fed the commercial diet FFG(M).

$\dagger$ There were only three $F_{3}$ litters of control mice because the first-litter $F_{2}$ control dam died before producing a third $\mathrm{F}_{\mathbf{3}}$ litter (see Fig. 1).

control group (Table 7). A detailed breeding study involving larger numbers of rats and mice is required to determine factors such as mating success, foetal resorption, still births and weaning in animals fed Chlorycel over successive generations.

It was difficult to measure accurately the amount of food consumed by the mice because fragments which fell into the cage were lost in the bedding material. However, it appeared that the experimental mice ate a similar quantity of Chlorycel (approximately $5 \mathrm{~g} / \mathrm{d}$ ) to the quantity of $F F G(M)$ eaten by the control mice. A more accurate assessment of food consumption by the rats was made in the metabolism experiment. The results are 


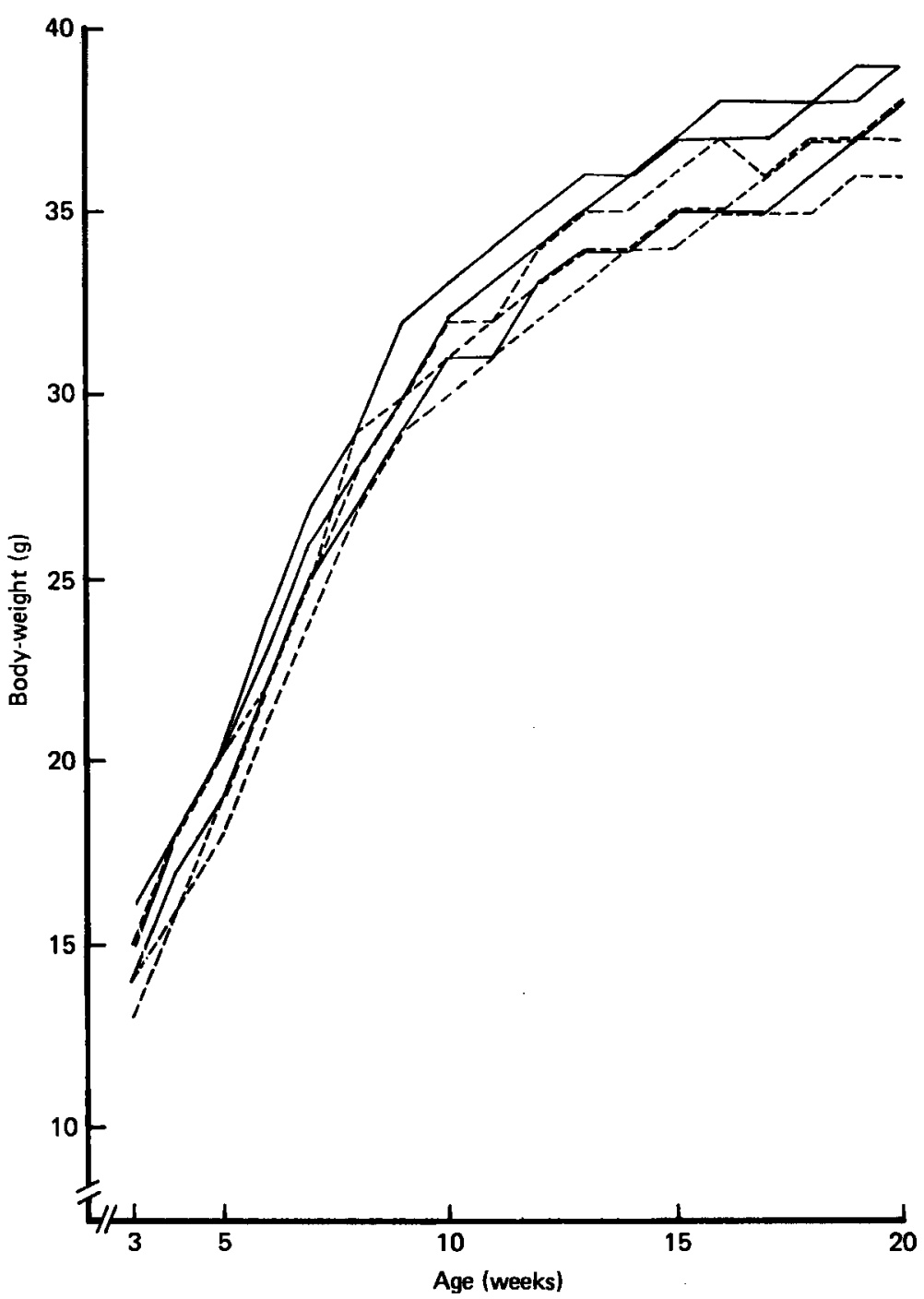

Fig. 2. A comparison of the growth curves for three female litter-mate experimental mice from the second generation with the growth curves for three female litter-mate control mice. (-), control diet; $(---)$, experimental diet.

summarized in Table 8 from which it can be seen that the experimental rats ate less (approximately $13.5 \mathrm{~g}$ Chlorycel/d) than the controls (approximately $16 \mathrm{~g}$ diet $4 \mathrm{I} \mathrm{B/d}$ ). Similar results were obtained in the first metabolism experiment. The experimental rats produced softer faecal pellets and a more turbid urine than their litter-mate controls. Post mortem examination revealed a larger caecum than found in the control rats and smaller fat deposits in the abdominal viscera of the experimental rats.

Body-weight gain, general appearance (including incisor pigmentation in the rats) and behaviour of the experimental rats and mice were similar to those of their respective control groups. A detailed study of the gain in body-weight was made for three female litter-mate mice from the second litter of the second generation $\left(F_{2}\right)$ control and experimental groups. 


\section{S. A. Khalawan, J. C. Elliott and R. W. Fearnhead}

Table 8. A summary of the results obtained from the second metabolism experiment in which four 28-day-old female rats were fed the yeast (Saccharomyces cerevisiae) and alga (Chlorella pyrenoidosa) food pellets (Chlorycel) and three female litter-mate control rats were fed the commercial diet $4 \mathrm{I} B$ for a period of $34 \mathrm{~d}$

\begin{tabular}{|c|c|c|c|c|c|c|c|}
\hline \multirow{3}{*}{$\begin{array}{l}\text { Total body-weight } \\
\text { gained }(\mathrm{g})\end{array}$} & \multicolumn{4}{|c|}{ Experimental } & \multicolumn{3}{|c|}{ Control } \\
\hline & 4 & 3 & 6 & 7 & 3 & 4 & 5 \\
\hline & 77 & 68 & 71 & 83 & 79 & 80 & 82 \\
\hline $\begin{array}{l}\text { Total food consumed'(g) } \\
\text { Food conversion (g food } \\
\text { eaten } / \mathrm{g} \text { body-weight } \\
\text { gained) }\end{array}$ & $\begin{array}{l}448 \\
5.8\end{array}$ & $\begin{array}{l}424 \\
6.2\end{array}$ & $\begin{array}{r}447 \\
6.3\end{array}$ & $\begin{array}{c}478 \\
5.8\end{array}$ & $\begin{array}{r}545 \\
6.9\end{array}$ & $\begin{array}{l}542 \\
6.8\end{array}$ & $\begin{array}{r}564 \\
6.9\end{array}$ \\
\hline Apparent digestibility (\%) & $68 \cdot 5$ & 68 & - & 68.8 & $69 \cdot 8$ & - & $70 \cdot 3$ \\
\hline
\end{tabular}

The growth curves for these mice are compared in Fig. 2 from which it can be seen that the body-weight of the experimental mice increased at a similar rate to that of controls. This observation was true for all the mice in this study until they were approximately 5 months old. The body-weight of the control mice continued to increase slowly after this age and they showed a marked tendency to become obese. Their general appearance usually declined after about one year of age and none survived beyond the age of 15 months. The experimental mice however, showed little tendency towards further increase in body-weight after a steady adult weight was reached. The breeding stock of the experimental mice from the first three generations was continued on Chlorycel but showed no obvious signs of obesity or ill-health, and none of these experimental mice died during the experiment. Five of them were at least 2 years old when they were killed.

\section{Reduction of fluoride content in culture medium and dietary salt supplements}

The biomass (produced in culture media prepared with analytical grade salts) contained $60-80 \mu \mathrm{g}$ fluoride $/ \mathrm{kg}$ dry weight. The major portion of this fluoride was derived from the analytical grade phosphates, which contained 2-5 mg fluoride $/ \mathrm{kg}$ and contributed 3-4 $\mu \mathrm{g}$ fluoride/l culture medium. The culture medium prepared with the hydroxyapatite-treated stock solutions contained less than $2 \mu \mathrm{g}$ fluoride/l and the biomass produced in this medium contained approximately $30 \mu \mathrm{g}$ fluoride $/ \mathrm{kg}$ dry weight. The yield of biomass in the hydroxyapatite-treated culture medium was similar to that in the untreated medium used as control.

The fluoride concentration in the analytical grade $\mathrm{CaCO}_{3}$ and $\mathrm{CaHPO} \mathrm{H}_{4} \cdot 2 \mathrm{H}_{2} \mathrm{O}$ used as salt supplement in Chlorycel was approximately 5 and $12 \mathrm{mg} / \mathrm{kg}$ respectively. Consequently, these salts contributed approximately $150 \mu \mathrm{g}$ fluoride $/ \mathrm{kg}$ diet. However, the $\mathrm{CaCO}_{3}$ and $\mathrm{CaHPO}_{4} \cdot 2 \mathrm{H}_{2} \mathrm{O}$ prepared with hydroxyapatite-treated reagent solutions contained 0.2 and $0.8 \mathrm{mg}$ fluoride $/ \mathrm{kg}$. The three batches of 'low-fluoride Chlorycel' (produced with biomass from the hydroxyapatite-treated medium and these 'low-fluoride calcium salt supplements') contained 60, 45 and $50 \mu \mathrm{g}$ fluoride/ $\mathrm{kg}$ diet respectively. This 'low fluoride Chlorycel' was not used in the feeding study.

\section{DISCUSSION}

The present study has demonstrated that a nutritionally adequate diet, with a level of fluoride between 100 and $300 \mu \mathrm{g} / \mathrm{kg}$ can be prepared with Chlorella and yeast biomass produced under controlled and reproducible conditions. The diet, Chlorycel, effected growth and reproduction in rats and mice similar to the growth and reproduction in controls fed with the commercial diets.

Yeast is produced on a large scale commercially and recently Endo et al. (1974) described 
a highly-successful fermentation-type process for the mass culture of Chlorella in the dark. It is therefore technically possible to produce the basic raw materials under strictly controlled conditions in large reproducible batches. The main advantage of this method for producing an experimental diet is the availability of plant, machinery and technical expertise. Although Chlorella was a minor constituent in the diet it made Chlorycel more readily acceptable to rats and mice. It is known that the lipid content of Chlorella can be varied from approximately $5 \%$ to more than $50 \%$ of the total biomass according to the method and age of the culture (Fogg \& Collyer, 1953; Milner, 1953). The production of Chlorella by a more efficient system in the fermenter (Endo \& Shirota, 1972), and cultured to yield a higher cell lipid level, would provide more alga-lipid in Chlorycel and allow for the reduction in the quantity of maize oil in the diet. This would increase the quantity of material that can be produced under controlled conditions. It would therefore seem that it should be possible to produce Chlorycel on a sufficiently large scale for general use in animal experiments involving fluoride metabolism. This is important because commercial diets for the laboratory rat and mouse usually contain variable amounts of fluoride ranging from approximately 5 to over $20 \mathrm{mg}$ fluoride $/ \mathrm{kg}$ dry weight. It is not surprising, therefore, that the hard tissues of young adult laboratory rats usually contain more than $400 \mathrm{mg}$ fluoride/ $\mathrm{kg}$ dry weight.

It appears from Table 5 that the $\mathrm{Ca}, \mathrm{Mn}$ and $\mathrm{Cu}$ levels in Chlorycel are determined by the levels of the salt supplements added to the diet (Table 3 ) and not from the biomass. It would seem possible therefore to produce a minimum $\mathrm{Ca}$-, $\mathrm{Mn}$ - or $\mathrm{Cu}$ - containing diet by excluding the appropriate salt supplements from the diet. Thus Chlorycel could also be used in feeding experiments to study, in greater detail, some of the established biological roles of $\mathrm{Ca}, \mathrm{Mn}$ and $\mathrm{Cu}$ as well as the relationship between $\mathrm{Ca}$ and $\mathrm{F}$ in rats and mice.

The present study has also shown that the diet can be produced with a very low level of fluoride (approximately $50 \mu \mathrm{g} / \mathrm{kg}$ ). The method involving the use of hydroxyapatite was highly effective and resulted in a large reduction in the level of fluoride in the diet. This very low-fluoride diet ought to make possible a thorough investigation of the vexed question of whether fluorine is an essential trace element.

The authors thank Mr D. S. Miller at Queen Elizabeth College, London for his kind assistance with the evaluation of the digestibility of Chlorycel in the rats, Dr J. Eastoe at The Royal College of Surgeons, London, for the amino acid analyses on the alga and yeast samples and the Medical Research Council for their financial support in part through grant no. G 970/ IOB.

\section{REFERENCES}

Adler, P. (1970). Wld Hlth Org. Monogr. Ser. no. 59, p. 323.

Casey, R. P. \& Lubitz, J. A. (1963). Fd Technol. 17, 48.

Combs, G. F. (1952). Science, N.Y. 116, 453.

Endo, H., Nakajima, K., Chino, R. \& Shirota, M. (1974). Agric. Biol. Chem. 38, 9.

Endo, H. \& Shirota, M. (1972). In Fermentation Technology Today, p. 533 [G. Tergui, editor]. Japan: Soc. Ferment. Technol.

Fogg, G. E. \& Collyer, D. M. (1953). In Algal Culture: from Laboratory to Pilot Plant, p. 177 [J. S. Burlew, editor]. Washington, D.C.: Carnegie Institution of Washington.

Fowden, L. (1952). Biochem. J. 52, 3 IO.

Fowden, L. (1954). Ann. Botany 18, 257.

Harris, E. E., Hajny, G. J. \& Johnson, M. C. (1951). Ind. Engng Chem. 43, 1593.

Ketchum, B. M., Lillick, L. \& Redfield, A. C. (1949). J. Cell. comp. Physiol. 33, 267.

Klose, A. A. \& Fevold, H. L. (1947). Archs Biochem. 13, 349.

Lindan, O. \& Work, E. (195I). Biochem. J. 48, 337.

Lubitz, J. A. (1963). J. Fd Sci. $28,229$.

McCann, H. G. \& Fath, E. H. (1958). J. biol. Chem. 231, 869. 


\section{S. A. Khalawan, J. C. Elliott and R. W. Fearnhead}

Milner, H. W. (1953). In Algal Culture: from Laboratory to Pilot Plant, p. 285 [J. S. Burlew, editor]. Washington, D.C.: Carnegie Institution of Washington.

Murlin, J. R., Edwards, L. E. \& Hawley, E. E. (1944). J. biol. Chem. 156, 785.

Myers, J. (1947). Plant Physiol. 22, 590.

Paschke, R. F. \& Wheeler, D. H. (I954). J. Am. Oil Chem. Soc. 31, 8 I.

Schlenk, H., Mangold, H. K., Gellerman, J. L., Link, W. E., Morrissette, R. A., Holman, R. T. \& Heyes, H. (1960). J. Am. Oil Chem. Soc. 37, 547.

Singer, L. \& Armstrong, W. D. (1965). Analyt. Biochem. ro, 495.

Spackman, D. H., Stein, W. H. \& Moore, S. (1958). Analyt. Chem. 30, 190.

Spoehr, H. A. (1951). Proc. Am. Phil. Soc. $90,62$.

Spoehr, H. A. \& Milner, H. W. (1949). Plant Physiol. $24,120$.

Volker, J. F., Hodge, H. C., Wilson, H. J. \& van Voorhis, S. N. (1940). J. biol. Chem. r34, 543. 